\title{
MAKNA TANAH LELUHUR BAGI NAOMI BERDASARKAN RUT 1:1-22
}

\author{
Nelci Nafalia Ndolu \\ Dosen Sekolah Tinggi Agama Kristen negeri Kupang \\ nelcinafaliandolu@gmail.com \\ Marsi Bombongan Rantesalu \\ Dosen Sekolah Tinggi Agama Kristen negeri Kupang \\ marsibombongan@gmail.com
}

\begin{abstract}
The Meaning of Ancestral Land For Naomi Based on Ruth 1: 1-22. The story of Naomi in Ruth 1: 1-22 is closely related to her ancestral land in Bethlehem-Judah. In Ruth 1: 1-3, Naomi is told to make a choice to leave her ancestral land. But Ruth 1: 6 explains that Naomi finally chose to return to her ancestral lands in Bethlehem-Judah after experiencing various suffering and tragedies in the land of Moab. Naomi's choice implied Naomi's perception of the economic, cultural, political and religious meaning of her ancestral land. Based on Ruth 1: 6-19-22, Naomi continues to acknowledge her ancestral land as the "mother" who gave birth to her, always faithfully welcomes her return, treats all the pain of her life; and even guarantee the prosperity of his life, the place that guarantees the rights of life and the social as a widow, and a safe place to worship faithfully to Allah the giver and the owner of his ancestral land.
\end{abstract}

Keywords: Ancestral Land, Naomi, Ruth 1: 1-22

\begin{abstract}
Abstrak
Makna Tanah Leluhur Bagi Naomi Berdasarkan Rut 1:1-22. Kisah Naomi dalam Rut 1:1-22 berkaitan erat dengan tanah leluhurnya di Betlehem-Yehuda. Dalam Rut 1:1-3, Naomi dikisahkan membuat pilihan untuk meninggalkan tanah leluhurnya. Namun Rut 1:6 menjelaskan bahwa Naomi akhirnya memilih untuk kembali ke tanah leluhurnya di Betlehem-Yehuda setelah mengalami berbagai penderitan dan tragedi di Moab tanah rantau. Pilihan Naomi tersebut tersirat persepsi Naomi tentang makna ekonomis, budaya, politis dan religious dari tanah leluhurnya. Berdasarkan Rut 1:6-19-22, Naomi tetap mengakui tanah leluhur nya sebaga "ibu" yang telah melahirkannya, selalu setia menyambut kepulangannya, mengobati semua kepedihan hidupnya; dan bahkan menjamin kesejahtraan hidupnya, tempat paling menjamin hak-hak hidup dan sosial sebagai seorang janda, dan tempat yang aman untuk beribadah dengan setia kepada Allah sang pemberi dan pemilik tanah leluhurnya.
\end{abstract}

Kata Kunci: Tanah Leluhur, Naomi, Rut 1:1-22; 


\section{Pendahuluan}

Dilistone menyatakan bahwa tanah memiliki makna ekonomis, budaya, religius, dan politis, . 1 Secara ekonomis, tanah adalah media yang menyediakan makanan dan, minuman. Sisi budaya dari tanah kala tanah dipersepsikan sebagai "ibu" yakni pihak yang melahirkan dan membesarkan; yang menjamin kehidupan. Secara religius, tanah senantiasa dikaitkan dengan keyakinan bahwa kehidupan berasal dari tanah dan tanah yang diberikan leluhur berfungsi untuk mempertahankan hidup. Keempat, secara politis: tanah mampu mengakomodir segenap kepentingan kehidupan masyarakat lainnya.

Sekaitan dengan makna di atas, kitab Rut 1:1-22 mengisahkan relasi Naomi dan keluarganya dengan tanah leluhur mereka yang diterpa isu kelaparan. Mereka memilih untuk meninggalkan tanah leluhur mereka yang secara iman merupakan tanah pemberian Allah. Secara ekonomis merupakan tanah yang menghasilkan gandum dan jelai dan penghasil " susu dan madu'nya, dari segi budaya merupakan warisan leluhur yang harus dijaga dengan baik, dan secara politik menunjukkan kedaulatan mereka di tengah kedua belas suku Israel. Mereka justru meninggalkan tanah leluhur mereka di Betlehem dan berencana menetap di Moab yang diyakini sebagai tanah yang subur yang dapat memberikan jaminan kehidupan yang lebih baik kepada mereka. Alih-alih ingin hidup bahagia di negeri Moab, tanah yang subur tersebut mereka justru ditimpa oleh berbagai kemalangan. Elimelek dan kedua anak laki-laki meninggal di tanah Moab. Naomi yang telah menjanda tidak mampu meneruskan hidupnya di Moab. Ia memilih kembali ke Betlehem, tanah kelahirannya dengan sejuta asa yang akhirnya mewujud nyata yakni mereka hidup sejahtra dengan kecukupan makanan, memiliki tanah, menantu dan cucu (Rut 2-4)

Kisah keluarga Elimelek tersebut selalu dibacakan setiap perayaan pentakosta di sinagoge. Tujuannya adalah mendidik pemuda-pemudi Israel untuk memahami bahwa tanah Kanaan dengan segala eksistensinya yang gersang, kering, perubahan musim yang sering terjadi namun dengan pengolahan yang tepat didukung dengan sistem pemerintahan yang stabil akan menjadi tempat kediaman yang lebih nyaman, menjanjikan kesejahteraan dan kemakmuran hidup.

Tanah leluhur patut dipandang sebagai berkat Allah yang patut dicintai, dijaga dan diolah untuk kesejahteraan hidup yang lebih baik. Persoalan kemiskinan adalah persoalan manusia bukan tanah. ${ }^{2}$ Cara dan pendekatan terhadap tanah yang harus dirubah. Anugrah pekerti berpendapat bahwa kemakmuran ditentukan oleh kompetisi insani bukan oleh kekayaan sumber daya alam. Otak atau kompetisi manusialah yang menciptakan nilai tambah yang memberikan penghasilan yan lebih hingga manusia bisa mengangkat dirinya dari sekedar hidup. ${ }^{3}$ Berdasarkan latar penulisan diatas, maka penelitian ini diberi judul: Makna Tanah Leluhur bagi Naomi Berdasarkan Rut 1:1-2-2 . Adapun rumusan masalah yang akan diteliti adalah bagaimana makna tanah leluhur bagi Naomi berdasaran Rut 1:1-22

1 F.W Dillistone, "The Power of Symbol : Daya Kekuatan Symbol", (Yogyakarta:Kanisius, 2002), 52-54

2 Eben Nuban Timo, "Pewarta Firman Pecinta Budaya: Mendengar dan Melihat Allah dalam Tradisi”, ( Jakarta: BPK Gunung Mulia, 2005), 19

3 Anugrah Pekerti, "Globalisasi, Pembelajaran dan Kemanusiaan: Tantangan untuk cendekiwan Kristen, dalam seri membangun Bangsa: Pembelajaran memasuki Era Kesejagatan", (Jakarta: PT Sinar Agape Press,1998), 95 


\section{Metode}

Metode yang digunakan adalah analisis naratif. Analisis naratif adalah cabang dari kritik sastra yang dilakukan dengan menganalisis adegan, alur, waktu, watak, sudut pandang narrator dalam teks Rut 1:1-22.4 Metode ini pilih untuk menemukan makna tersurat maupun tersirat dar narasi Rut 1:1-22.

\section{Hasil dan Pembahasan}

Adegan

Adapun pembagian setiap adegan ini penulis lakukan dengan memperhatikan waktu, tempat serta tokoh yang berperan didalamnya.

Adegan I (ayat 1-2)

\begin{tabular}{|c|c|}
\hline Adegan 1 & $\begin{array}{l}\text { Adegan pertama terdapat pada ayat } 1-2 \text { dari teks. Bagian ini } \\
\text { merupakan pendahuluan dari narator yang berisi tentang keluarga } \\
\text { Elimelek yang mengungsi dari Betlehem menuju ke Moab karena } \\
\text { kelaparan yang terjadi di Betlehem. }\end{array}$ \\
\hline Tempat & Betlehem Yehuda \\
\hline Waktu & Pada masa para Hakim memerintah \\
\hline Tokoh & Elimelek, Naomi, Mahlon dan Kilyon \\
\hline
\end{tabular}

Adegan II (ayat 3-5)

\begin{tabular}{|l|l|}
\hline & \multicolumn{1}{|c|}{ Adegan kedua ini terdapat pada ayat 3-5 dari teks. Adegan ini } \\
Adegan 2 & $\begin{array}{l}\text { masih merupakan pendahuluan dari narator, namun kali ini berisi } \\
\text { informasi mengenai kehidupan keluarga Elimelek setelah menetap di } \\
\text { Moab. Elimelek meninggal setelah satu tahun menetap di Moab, } \\
\text { Pernikahan Mahlon dan Kilyon dengan perempuan Moab yakni Orpa dan } \\
\text { Rut, selanjutnya kematian Mahlon dan Kilyon sepuluh tahun kemudian. }\end{array}$ \\
\hline Tempat & Moab \\
\hline Waktu & Kemudian \\
\hline Tokoh & Elimelek, Naomi, Mahlon, Kilyon, Orpah dan Rut \\
\hline
\end{tabular}

Adegan III (ayat 6)

\begin{tabular}{|l|l|}
\hline Adegan 3 & $\begin{array}{l}\text { Naomi bersama kedua menantunya yakni Opra dan Rut } \\
\text { berkemas untuk pulang ke Betlehem. Sebab dari Moab Naomi } \\
\text { mendengar bahwa telah terjadi kelimpahan gandum dan jelai di } \\
\text { Betlehem. }\end{array}$ \\
\hline Tempat & Moab \\
\hline Waktu & "kemudian" setelah kematian Mahlon dan Kilyon. \\
\hline Tokoh & Naomi, Orpah dan Rut \\
\hline
\end{tabular}

Adegan IV (ayat 7-18)

\begin{tabular}{|c|c|}
\hline Adegan 4 & $\begin{array}{l}\text { Pada adegan ini digambarkan percakapan antara Naomi dengan } \\
\text { Orpa dan Rut dalam perjalanan menuju Betlehem. Isi percakapan adalah } \\
\text { Naomi meminta Orpa dan Rut kembali ke Moab. Akhir percakapan } \\
\text { mereka adalah Orpa kembali ke Moab dan Rut melanjutkan perjalanan } \\
\text { bersama Naomi ke Betlehem }\end{array}$ \\
\hline Tempat & Di jalan menuju Betlehem Yehuda \\
\hline Waktu & - \\
\hline Tokoh & Naomi, Orpah, dan Rut \\
\hline
\end{tabular}

4 Sitompul dan Ulrich Beyer, "Metode Penafsiran Alkitab," (Jakarta: BPK Gunung Mulia, 2006), 202-203 
Adegan V (ayat 19-22)

\begin{tabular}{|l|l|}
\hline Adegan 5 & \multicolumn{1}{|c|}{ Naomi dan Rut melanjutkan perjalanan dan tiba di Betlehem. } \\
Mereka disambut oleh perempuan-perempuan kota yang mengenal \\
Naomi
\end{tabular}

\section{Plot, Tokoh, Karakterisasi, Latar, Waktu dan Sudut Pandang Narator}

Betlehem Vs Moab (ayat 1-5)

Narator memulai kisah Naomi dengan menjelaskan situasi yang terjadi di Betlehem tanah leluhurnya. Betlehem merupakan tanah leluhur Naomi sebab berdasarkan durasi (waktu) cerita, kisah ini terjadi pada masa Hakim-Hakim masa dimana Betlehem merupakan tanah yang dianugerahkan Allah kepada nenek moyang untuk memenuhi kebutuhan dasar sebagai manusia yang awal hingga akhir hidupnya terikat dan bergantung pada tanah dan disinilah mereka mengekspresikan diri dan kehidupan (Yos 13:8-19:51). Situasi yang terjadi menerpa tanah leluhur Naomi adalah kelaparan (רָָָָ)

Narator memberikan informasi situasi kelaparan melalui penyebutan latar tempat cerita yakni Betlehem. Scara harafiah Betlehem artinya "rumah roti", justru mengalami רָָָּ "situasi kekurangan makanan yang sangat serius. Tanah di Betlehem adalah tanah paling subur. Hal ini disebabkan Betlehem memiliki lahan yang baik untuk budidaya gandum dan jelai karena berada di lembah Sungai Yordan yang beroleh air dari sungai-sungai yang bermuara ke Sungai Yordan. ${ }^{5}$ Artinya, Betlehem adalah pusat lahan gandum, jelai bahan dasar pembuatan roti. Berdasarkan durasi cerita "masa Hakim-Hakim" beberapa ahli menyatakan penyebab kelaparan tersebut adalah land-grabing dari suku Midian dan Amalek (Hak 6:1-6). ${ }^{6}$ Namun, ada juga ahli yang lebih cenderung menyatakan bahwa kelaparan tersebut disebabkan oleh kekeringan yang berkaitan dengan curah hujan.$^{7}$

Dalam masyarakat agraris, kelaparan merupakan bencana yang efeknya amat serius bagi kehidupan ekonomi dan sosial. ${ }^{8}$ Narator mengambarkan respon Naomi dan keluarganya dengan situasi tersebut dengan kata " lalu pergilah" mereka dari Betlehem tanah leluhur mereka menuju Moab untuk mendapatkan makanan. Kondisi awal keluarga ketika berangkat masih lengkap yakni Naomi bersama suaminya dan kedua anaknya Kilyon dan Mahlon. Keputusan mereka untuk pindah menunjukkan karakter Naomi dan keluarganya terhadap rumah dan tanah leluhur mereka. Elimelek sebagai suami bertindak sebagai pahlawan dalam rumah tangganya tetapi tidak sebagai pahlawan yang menjaga rumah dan tanah leluhurnya. Naomi pun menunjukkan diri sebagai istri yang hanya taat kepada Elimelek. Benitez menyebutnya wanita yang mulia dan bijaksana. ${ }^{9}$ Mahlon dan Kilyon pun menunjukkan sifat serupa. Menurut Van de Brick, Elimelek sendiri pergi merantau, mencari untung ke negeri tetangga karena tidak dapat atau tidak mau lebih lama

\footnotetext{
${ }^{5}$ Norman K. Gottwald, " A Hebrew Bible: A Socio Literary Introduction”, (London :Oxford University Press,1962), 41-21

6 J.D Douglas, “Ensiklopedi Masa Kini Jilid 1: A-L”, (Jakarta: YKBK/OMF,2007), 355

7 Robert L Hubbard, The Book of Ruth, (America: Erdmass Publishing, 1943), hal 85

8 Yongki Karman, "Tafsiran Kitab Rut”, (Jakarat: BPK Gunung Mulia,2009), 5

9 Milton Acosta Benitez, "Commentary on Ruth", Journal of Latin American Theology: Christian Reflection from the Latino South", Volume 11 No 11, 2016, 17, diakses 26 Mei 2019 https://books.google.co.id/books?id=Of1JDAAAQBAJ\&pg=PA27\&dq=naomi+on+Journal\&hl=id\&s a=X\&ved=0ahUKEwicn72qrrjiAhXJPI8KHRftAi4Q6AEIMTAB\#v=onepage\&q=naomi\%20on \%20Journ $\underline{\text { al\&f=false }}$
} 
lagi bertahan dengan kondisi kurangnya makanan di Betlehem. Perbuatan Elimelek menyatakan kurangnya rasa solidaritas dengan bangsa sendiri. ${ }^{10} \mathrm{~J}$. Hardee Kennedy berpendapat lain yakni keputusan keluarga Naomi untuk merantau ke Moab karena ada satu situasi "darurat" sehingga memaksa mereka untuk meninggalkan Betlehem. ${ }^{11}$

Moab adalah daerah yang dipilih oleh Naomi dan keluarganya sebagai daerah tujuan perantauan untuk mendapatkan sepotong roti untuk dimakan. Mengapa Moab dipilih oleh Naomi dan Elimelek? Secara geografi Moab adalah daerah yang sangat subur karena ketersediaan air dari beberapa sungai yakni Sungai Arnon, Sungai Nahaliel dan sungai Sered. Salah satu daerah yang terkenal saat itu adalah Dibon. Dibon adalah sebuah desa peradaban yang memiliki sistem pertanian yang tinggi. Dibon menjadi tempat sangat penting saat itu karena berfungsi sebagai tempat lumbung gandum bagi penduduk Moab dan tentu saja wilayah sekitar seperti Kanaan. Itulah alasannya Naomi dan keluarganya merantau ke Moab dengan tujuan bekerja memanen gandum dan jelai di ladang-ladang penduduk Moab. ${ }^{12}$

Di Moab, Elimelek dan keluarganya hidup sebagai לִִּּ "orang asing atau pendatang" yang tidak memiliki banyak kebebasan atau hak-hak terbatas terkait dengan kepemilikan tanah, pernikahan, hukum, partisipasi ibadah publik, dan kewajiban berperang. Untuk kehidupan sehari-hari, mereka mengandalkan kebaikan hati penduduk setempat. ${ }^{13}$ Permainan kata-kata pada ayat 1 digunakan kata לָּגוּר , maka pada ayat 2 dipakai kata

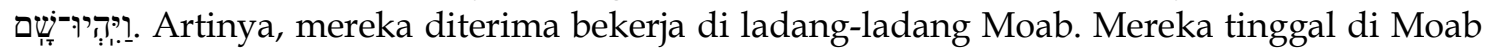
sebagai tenaga kerja asing dan mendapatkan makanan yang cukup untuk kebutuhan mereka sehari-hari. Sudut pandang narator dalam adegan 1 (ayat 1-2) adalah orang Israel meninggalkan tanah leluhur mereka hanya karena tidak lagi memberi kesejahtraan hidup akibat musim kemarau dan pencaplokan hasil tanah (land grabing). Mereka cenderung berpindah ke tempat yang subur seperti Moab..

Nasib Malang Naomi di Moab (3-5)

Narasi berlanjut dengan informasi kematian Elimelek di tahun pertama mereka menetap di Moab sebagaimana durasi waktu "kemudian". Kematian kepala keluarga dalam masyarakat patriarkat adalah sebuah pukulan berat. ${ }^{14}$ Keluarga tersebut kehilangan kepala keluarga dan jaminan perlindungan. Cerita berlanjut dengan pernikahan Mahlon dan Kilyon dengan perempuan Moab yakni Orpa dan Rut. Mahlon dan Kilyon menikahi perempuan Moab menunjukkan fungsi mereka sebagai laki-laki dalam usaha mempertahankan hidup di daerah rantau (Band Rut 2). Hal paling penting dari pernikahan tersebut adalah keberlangsungan garis keturunan. Naomi sendiri menunjukkan diri sebagai seorang ibu yang mengikuti pilihan anak-anaknya menikahi perempuan Moab walaupun bertentangan dengan hukum Perkawinan Israel (bdk Ul 23:1-8). Namun sekali lagi tragedi terjadi lagi dalam keluarga setelah sepuluh kemudian "lalu matilah " kedua anak laki-laki tanpa keturunan.

Situasi awal keluarga yang utuh kini menjadi kacau balau dengan meninggalnya

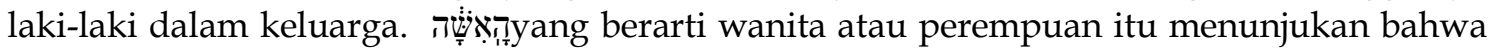
hanya tinggal Naomi seoranglah yang merupakan satu-satunya anggota keluarga Elimelek

10 Van den Brick, “Tafsiran Rut dan Ester",( Jakarta: BPK Gunung Mulia, 1970), 20-21

11 J. Hardee Kennedy, "Ruth, dalam The Broadman Bible Commentary Volume 2: Leviticus Ruth, (Broadman Press, 1970), 467

12W Reed," A Recent Analisys of Grain from Ancient Dibon in Moab", dalam Robert L. Hubbard, The Book of Ruth, (Amerika: Grand Rapid, 1943), 87

13Yongki Karman, 6

${ }^{14}$ Ibid., 92 
yang tertinggal.15 Dalam budaya patriakal, seorang perempuan janda yang ditinggal suaminya apalagi tanpa keturunan (anak laki-laki) merupakan sebuah musibah. ${ }^{16}$ Dengan kata lain seorang janda yang juga tidak memiliki anak secara otomatis menjadi masyarakat yang termarjinalkan. ${ }^{17}$ Dalam kasus ini bukan hanya Naomi saja yang menjadi janda namun juga kedua menantunya, istri dari Mahlon dan Kilyon. Walaupun tetap saja bahwa Naomi adalah yang paling berat bebannya karena harus ditinggal oleh suami dan kedua anaknya sekaligus. Kematian kedua anak laki-lakinya, menyadarkan Naomi bahwa tidak ada perlindungan lagi baginya di Moab.

Melalui kisah ini, narator hendak menyampaikan bahwa pilihan masyarakat Israel agraris yang meninggalkan tanah leluhur dan memilih tinggal di Moab bukanlah solusi yang tepat menghindari kelaparan di Betlehem. Banyak resiko yang dihadapi oleh mereka.

\section{Betlehem-Yehuda: Tanah Leluhur Memanggil Pulang (ayat 6-22)}

Narasi berlanjut dengan upaya Naomi memperbaiki memperbaiki keadaan dirinya dan kedua menantunya. Melalui kata " kemudian" alur cerita berlanjut pada keputusan Naomi untuk pulang ke tanah leluhurnya di Betlehem. Dia memilih untuk kembali ke

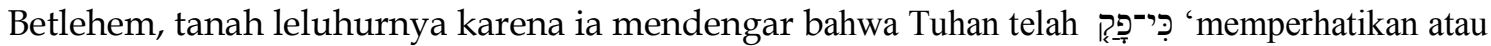
mengunjungi" umat-Nya dengan "memberikan makanan kepada mereka". Ukuran perhatian dan tanda kehadiran Tuhan adalah dengan keberhasilan panen yang dialami oleh umat-Nya. Tuhan telah memberkati tanah leluhurnya sehingga berkelimpahan makanan. Jika merujuk pada data para ahli Perjanjan Lama dalam buku Ensiklopedi Masa Kini, maka pergumulan orang Israel yang masih tinggal di Yerusalem terkait ladang-ladang gandum dan jelai yang rusak, ternak yang dirampas oleh orang Midian berbuah manis. Tuhan memperhatikan pergumulan orang Israel dengan mengutus Hakim Gideon memimpin perang melawan suku Amalek dan Midian. Gideon berhasil menghalau suku Midian dan Amalek dari Kanaan (Hak 6-8:28). Mereka bebas menggarap tanah mereka dengan menanam gandum, dan jelai. Tanpa tekanan serangan mereka memanen hasil ladang mereka dan menikmati hasilnya. Mereka tidak lagi kekurangan makanan berupa roti. Keadaan tersebut tersiar ke seluruh negeri, hingga ke telinga Naomi di Moab. Naomi pun bergegas kembali ke tanah airnya di Betlehem. Selain itu, Naomi memliki harapan besar untuk membangun kehidupan yang baru yang lebih baik bersama sanak keluarganya dan menyembuhkan dirinya sendiri (band Rut 4:3). Tanah kelahirannya menawarkan kekuatan materi, keamanan atau perlindungan, ketenangan, kenyamanan dan penghiburan. ${ }^{18}$

Narator menggambarkan bahwa ketiga orang janda itu berkemas untuk pulang ke Betlehem. Kata berkemas dalam bahasa aslinya digunakan kata "bangkit atau bangun". Setelah mengalami kesedihan karena sekali lagi harus ditinggal oleh anakanaknya, Naomi akhirnya bangkit atau bangun dari keterpurukan dan kesedihannya dan Rut pulang ke Betlehem. Dari Moab Naomi juga mendengar bahwa Tuhan telah (memperhatikan atau mengunjungi) umat-Nya. Ukuran perhatian dan tanda kehadiran Tuhan adalah dengan keberhasilan panen yang dialami oleh umat-Nya. Allah dalam kepemimpinan Gideon membersihkan Israel dari penyamun-penyamun pengembara yakni

\footnotetext{
15 Ibid., 91

16 Herbert G. May," The Books of Ruth, dalam: Interpreter's Concise Commentary Vol. II: Old Testament History", (USA: The Parthenon Press, 1984), 85

17 E. Jhon Hamlin," Surely Is The Future: A Commentary On The Book of Ruth," (Amerika: Eerdmans Company ,1996),10

18 Lois C. Dubin, "Fullness and Emptiness: Meditation on Naomi's Tale in the Book of Ruth, dalam Reading Ruth : Contemporary Women Reclaim a Sacred Story", Judith A. Kates \& Gail T Reimer, (Amerika: Ramdom House, 1994),132
} 
suku Amalek dan Midian. Israel hidup damai dengan menanam dan memanen gandum dan jelai di ladang-ladang mereka 20 tahun kemudian (Rut 2-4).

Kata "maka" menegaskan bahwa bahwa Naomi segera berangkat bersama-sama dengan kedua menantunya untuk pulang ke Betlehem setelah selesai berkemas. "Ketika" dalam perjalanan meninggalkan rumah mereka di Moab, Naomi sadar bahwa kedua menantunya hanya akan membawanya ke dalam masalah baru sehingga ia menyuruh mereka untuk pulang. Kedua, Naomi ingin agar kedua menantunya dapat menikah lagi. Satu-satunya harapan untuk memperbaiki status sosial mereka. ${ }^{19}$ Naomi menunjukkan karakter seorang mertua yang tidak ingin membebani hidup menantunya dan paham akan kebutuhan mereka. Namun karena kedua menantunya berkeras hati untuk ikut (ayat 10) maka sekali lagi Naomi meminta mereka untuk pulang dengan memberi pertimbangan yang cukup masuk akal bahwa ia tidak mempunyai anak laki-laki yang dapat mereka nikahi. Akhirnya Orpa menuruti Naomi dengan kembali ke Moab namun Rut tetap berkeras hati ikut bersama mertuanya itu. Rut menegaskan kepada Naomi bahwa ia juga bersedia menerima bangsa dan Allah Naomi "bangsamulah bangsaku...Allahmu Allahku". Rut siap hidup menurut norma-norma hukum, adat-istiadat, bahasa, pola hidup, dan bahkan menyembah Allah orang Israel. Ia siap untuk menyamakan agamanya dengan agama Naomi, menerima hal-hal yang baik dan buruk di di tanah leluhurnya Naomi.20 Ia berkomitmen untuk hidup dan mati di tanah leluhur Naomi. Rut menutup pernyataannya dengan sebuah bersumpah demi nama YHWH untuk menemani Naomi. ${ }^{21}$ Naomi pun berhenti memaksa Rut untuk kembali ke rumah orangtuanya. Kata "dan berjalanlah keduanya" menunjukkan bahwa mereka sepakat untuk meneruskan perjalanan menuju Betlehem tanah leluhur Naomi dan meneruskan hidup mereka hingga mati.

Alur cerita berlanjut dengan cepat bahwa mereka sudah tiba di Betlehem d dan kemunculan perempuan-perempuan kota yang menyambut Naomi dan Rut yang tiba di Betlehem. Mereka di sambut dengan sukacita "Naomikah itu?". Akan tetapi sukacita kegembiraan dan kebaikan perempuan-perempuan yang mewakili penduduk kota disambut dengan penolakan Naomi (ayat 20) "janganlah sebutkan aku Naomi, sebutkan aku Mara". Naomi berarti manis dan Mara berarti pahit sebuah bentuk protes Naomi atas kepahitan yang ia alami. Ia malu dengan kepahitan hidup dan kemalangan hidup yang ditemui selama hidup di Moab, tanah perantauan.

Dengan tangan yang penuh aku pergi, tetapi dengan tangan yang kosong TUHAN memulangkan aku. Naomi flashback terhadap kehidupannya yang penuh tragedi karena pilihannya dulu. Kepenuhan mengandung pengertian kepemilikan keluarga yang utuh yakni suami dan kedua anaknya yakni Mahlon dan Kilyon, masih memiliki perbendaharaan, masih merasa enak hidupnya ketika mereka merantau ke Moab. Namun, di Moab ia mengalami banyak kemalangan sehingga ia pulang dengan tangan kosong: tidak memiliki suami, anak-anak bahkan cucu, hidupnya melarat, dan menyedihkan. Ia merasa asing dengan dirinya sendiri. Ia hanya memiliki dua pilihan yakni dia harus membawa dan menceritakan kesedihan dan kepahitannya penduduk Betlehem untuk didengar dan diketahui, dan dia harus malu di hadapan Allah karena tanah leluhurnya, miliknya yang masih tersisa yang memberikan penghiburan kepadanya.

19 David Atkinson, , "Seri Pemahaman dan Penerapan Amanat Alkitab Masa Kini Rut", (Jakarta: Yayasan Bina Kasih,2005) , 62

20 Peniel C. D. Maiaweng \& Christina Ukung, "Apakah Rut, Perempuan Moab Adalah Penyembah TUHAN?" Jurnal JAFFRAY, Vol. 16, No. 2 (Oktober 2018):155-156, diakses 26 Mei 2019 https://media.neliti.com/media/publications/264784-apakah-rut-perempuan-moab-adalahpenyemb-5f93f726.pdf

${ }^{21}$ James T. Cleland, “The Intepreters Bible Vol 2”, (Nashville, Abingdon Press, 1953), 837 
TUHAN telah naik saksi menentang aku dan Yang Maha Kuasa telah mendatangkan malapetaka kepadaku. Dari perspektif Naomi, Tuhan yang disebut dengan sebutan El Shadday sebagai Allah yang Maha kuasa, Allah yang mencukupkan, Allah dari segala kekuatan memberi kesaksian yang memberatkan dirinya. Tanpa keraguan Naomi berbicara tentang Allah yang bertanggungjawab terhadap penuh kesejahteraan umatnya (shad) dan Allah yang sang pemusnah (shadad). ${ }^{22}$ Kesaksian Tuhan yang memberatkan dirinya membuat ia harus menanggung hukuman. Ayat 22 merupakan tambahan dari narrator yang menjelaskan bahwa Naomi dan Rut tiba di Betlehem pada musim menuai jelai. Artinya, jelai sudah ditabur di ladang, berbulir dan siap dipanen oleh orang Israel. Hal yang indah yang patut dibayangkan adalah Naomi disambut dengan bulir-bulir jelai yang melimpah di tanah Betlehem. Keadaan tersebut tentunya menguatkan imannnya kepada Allah yang selalu memberkati tanah airnya sebagai tempat mendapatkan makanan bagi hidupnya. Cerita tentang bulir-bulir jelai yang didengarnya di tanah Moab tidak hanya sekedar cerita. Dia sendiri menjadi saksi atas berkat Allah di atas tanah airnya, Betlehem. Situasi tersebut tentunya memungkinkan dirinya sebagai seorang perempuan, janda menjalani hidup yang lebih baik. Tentunya ia juga tidak malu dengan Rut, menantunya yang dibawanya dari Moab. Bulir-bulir jelai yang menguning di ladang menjadi sumber kesukaan dan harapan baru bagi mereka berdua hidup sejahtera di Betlehem. Lanjutan cerita Naomi pun berkisah tentang segala berkat Allah di tanah Betlehem, ( Rut 2-4). Sebuah gambaran bahwa Betlehem yang sempat kehilangan identitasnya sebagai penghasil jelai dan mengukuhkan Betlehem sebagai kota Roti dan memberi kehidupan secara ekonomis, budaya, politik dan religius bagi Naomi.

Sudut pandang narrator dalam bagian ini adalah orang Israel yang hidup menderita di tanah perantauan seperti di Moab pada akhirnya memilih kembali ke tanah leluhur yang telah dianugerahkan Allah dan diwariskan oleh nenek moyang mereka. Selain itu, tanah leluhur patut diperjuangkan walau terjadi kemarau sehingga tidak memberi hasil yang sangat banyak. Selain itu, kedaulatan politis tanah leluhur ditegakkan dari serangan pihak luar agar orang Israel dapat hidup aman, nyaman dan sejahtera. Narator memberi gambaran bahwa hidup ini adalah pilihan. Dalam kesulitan hidup terkadang tanpa sadar manusia mempersalahkan Tuhan dan tanah leluhurnya sehingga meninggalkanya. Manusia dituntut untuk setia terhadap Dia dan setia menjaga serta mengolah tanah leluhur yang Allah anugerahkan dan diwariskan oleh keluarga untuk hidup yang sejahtera.

\section{Makna Tanah Leluhur Bagi Naomi \\ Makna Ekonomi}

Penderitaan yang dialami Naomi di Moab dan berita kelimpahan di Betlehem mengubah pandangannya tentang tanah leluhurnya. Naomi kembali bersahabat dengan tanah leluhurnya. Naomi menyadari tanah Moab tidak dapat menjadi tumpuan hidupnya sebagai seorang perempuan yang tanpa suami dan tanpa anak. Tanah perantauan di Moab telah merenggut semua kebahagiaannya yakni kematian suami dan anak-anaknya. Naomi tidak mau mengalami resiko yang lebih besar di Moab.

Manusia dan tanah saling membutuhkan. Pilihan Naomi ke Betlehem tanah leluhurnya menegaskan kebutuhannya untuk mandiri secara ekonomi. Ia kembali menaruh penghargaannya tentang nilai ekonomis tanah leluhurnya itu; tanah yang subur penghasil gandum dan jelai, pusat roti sebagaimana nama Betlehem yakni kota roti. Sakenfeld menyatakan bahwa Naomi membutuhkan betlehem tanah leluhur sebagai tempat yang

${ }^{22}$ K. D Sakenfeld," Naomi's Cry: Reflection on Ruth 1: 20-22,." dalam A God So Near: Essyas on Old Testament Theology in Honor of Patrick D, Brent A. Strawn dan Nancy R. Bowen Miller, (Winona Lake:Eisenbrauss, 2003), 135-137 
aman bagi Naomi untuk mandiri secara ekonomi. ${ }^{23}$ Tentu harapan tersebut logis karena berdasarkan Rut 4:3 ia mewarisi tanah kepemilikan leluhurnya yang sejatinya merupakan modal ekomoni yang sangat baik Naomi untuk kembali hidup sejahtera. Siquans menyatakan Naomi pemilik sah tanah leluhurnya sang suami yang telah meninggal.24 Naomi dapat bercocok tanam atau memperkerjakan orang-orang untuk menanam gandum dan jelai di tanah miliknya warisan leluhurnta untuk memenuhi kebutuhan hidupnya sehari hari. Mengingat bahwa daerah yang memiliki gandum, jelai dan roti menjadi pengendali sistem perekonomian saat itu. Gandum tidak hanya digunakan untuk memenuhi kebutuhan pokok sehari-hari, ritual ibadah tetapi juga dipakai sebagai uang dalam perdagangan. Selain itu, gandum juga digunakan sebagai mahar perkawinan. Oleh karena itu harapan Naomi untuk kembali hidup sejahtra di tanah leluhurnya bukan sesuatu yang mustahil. Kolimon mengemukakan bahwa orang yang sejahtera adalah orang yang memiliki tanah dan mengolahnya. Sebaliknya orang yang jauh dari tanahnya akan hidup dalam kemiskinan dan perbudakan. 25

Setidaknya jika ia tidak mampu bercocok tanam karena sudah tua, ia masih dapat memungut bulir-bulir jelai atau gandum yang ditinggalkan pengerja-pengerja di ladangladang di Betlehem (Rut 2:1-2, Im 19:9-10, Ul 24:19). Atau ia dapat menyewakan tanah untuk dikerjakan dan mendapat bagiannya sebagai pemilik tanah. Ia pun dapat menjual sebagian tanah leluhurnya untuk bertahan hidup dengan kesepakatan bersama seluruh anggota keluarga suku yang lain. Karman menyatakan tanah leluhurnya diberikan oleh Allah untuk memenuhi kehidupan sehari-hari keluarga. ${ }^{26}$ Dalam konteks masyarakat agraris, Kolimon pun berpendapat bahwa orang yang sejahtera adalah orang memilik tanah, menjaga dan mengolahnya tanahnya itu. Sebaliknya orang yang tidak memiliki tanah akan hidup dalam kemiskinan dan perbudakan. ${ }^{27}$

\section{Makna Budaya}

Kepulangan Naomi pun menegaskan nilai budaya tanah leluhur baginya. Naomi kembali mempersepsikan tanah leluhurnya sebagai "ibu" , tempat ia lahir, bertumbuh besar, menikah dan menikah dengan suami yang telah meninggal dan melahirkan anak-anaknya pula yang telah tiada, seraya menaruh harap menjalani sisa akhir hidupnya di tanah leluhurnya dengan damai. Sebagai " ibu" tanah leluhurnya tidak akan menolak kepulangannya tetapi akan menyambutnya kembali dengan sukacita bahkan menjamin kehidupannya dengan kesuburan dan kelimpahan makanan. Keyakinan tersbut selaras dengan tindakan penyambutan hangat dari perempuan-perempuan Betlehem (ayat 19).

Pemaknaan tersebut mengisyaratkan persepsi Naomi sebagai "anak" tdengan prinsip relasi mutual-equalis. Naomi siap "bertemu dan merangkul" semua kebaikan tanah leluhurnya sekaligus siap bertanggungjawabnya untuk menjaga tanah leluhurnya. Menarik bahwa pasal 2-4 member gambaran Naomi melaksanakan kewajibannya sebagai generasi

${ }^{23}$ K. D. Sakenfeld, " The Story of Ruth: Economic Survival” In Reality Day : Essays in Archaelogical and Biblical Intrepretation, (Atlanta: Scholars, 1999), 115-120

${ }^{24}$ Agnethe Siquans," Foreignness and Poverty in the Book of Ruth: A Legal Way for a Poor Foreign Woman to Be Integrated into Israel “, Journal of Biblical Literature Vol. 128, No. 3 (Fall, 2009), .443-452

${ }^{25}$ Merry Kolimon, "Teologi Ramah Tanah di Timor Barat", dalam : Zakaria Ngelow \& Lady (ed), "Teologi Tanah: Perspektif Kristen terhadap ketidakadilan Sosio-ekologis di Indonesia", Makassar: Oase Intim, 2015, 25A

${ }^{26}$ Yongki Karman, “Bunga Rampai Teologi Perjanjian Lama”, (Jakarta:BPK GM,2004), 85

27 Merry Kolimon, "Teologi Ramah Tanah di Timor Barat”, dalam : Zakaria Ngelow \& Lady (ed), "Teologi Tanah: Perspektif Kristen terhadap ketidakadilan Sosio-ekologis di Indonesia", (Makassar: Oase Intim, 2015), 25-26 
bertanggungjawab untuk meneruskan tanah warisan leluhurnya melalui strateginya untuk menikahkan Rut dan Boas. Anak yang lahir dari pernikahan tersebut yakni Obed mewarisi tanah leluhur Elimelek sehingga generasi keluarga tersebut pun tetap berlanjut.

\section{Makna Religius}

Penyebutan nama Tuhan terkait dengan kemakmuran di tanah leluhur yang menuntunya untuk pulang ke tanah leluhurnya dan pernyataan Naomi tentang hukuman Tuhan selama di Moab (ayat 6, 21), Naomi menyatakan pandangan religiusnya tentang tanah leluhurnya memiliki aura mitis dan magis karena penguasanya yakni ALLAH punya kuasa untuk mendatangkan kebaikan dan keburukan. Dalam konteks agraris Israel kuno, Allah dipercayai berkuasa menurunkan hujan es yang membuat tanaman mati, Allah juga berkuasa untuk menurunkan wabah penyakit bagi tumbuh-tumbuhan (bdk. Kel 10:12,15; ). Bahkan Allah juga berkuasa untuk membuat huru hara sehingga orang Israel tidak dapat menikmati hasil panen mereka (Ul 28:20, Hak 6 ). Sebaliknya Allah diyakini sebagai pemberi hujan yang menjamin ketersediaan air bagi pertanian sehingga hasil tanaman gandum, jelai, buah-buahan dan pohon-pohon zaitun melimpah serta menjamin stabilitas politik sehingga orang Israel kuno yang agraris bisa memanen dan menikmati hasil pertanian mereka (Ul 28;11-14, Zak 10:1-2)

Namun manusia punya kuasa dan otoritas untuk mendatangkan kebaikan dan keburukan tanah leluhurnya. Kekuasaan Allah tersebut menuntut orang Israel untuk hidup taat setia beribadah kepada Allah karena Allah yang memberikan tanah. Itulah yang tersirat dalam jawaban Naomi “ ...Karena TUHAN telah naik saksi menentang aku dan Yang Maha Kuasa telah mendatangkan Malapetaka kepadaku". Naomi meyakini tanah leluhurnya adalah pemberian Allah kepadanya yang bukan hanya sebagai tempat untuk berdiam, dan menikmati berkat Allah tetapi merupakan tempat untuk menyembah Allah dengan taat dan setia tanpa ada yang mengekang dan merintangi. Bruegeman menyatakan bahwa tanah memiliki hubungan erat antara umat dengan Tuhannya selain sebagai tempat tinggal. ${ }^{28}$ Bahkan Inge menegaskan tanah leluhur merupakan tanah bersama Tuhan, tempat yang penuh kenangan dan harapan. ${ }^{29}$ Tanah leluhur patut dihargai dan dijaga eksistensinya dalam sikap yang setia beribadah kepada Allah. Allah Israel Allah yang cemburu kepada orang Israel yang menyembah kepada berhala dan berkuasa untuk mengutuk mereka dengan kelaparan bahkan memberkati mereka dengan kelimpahan makanan (Hak 2:6-14, Ul 28). ${ }^{30}$

\section{Makna Politis}

Kegemparan penduduk Betlehem dan sambutan hangat perempuan-perempuan Betlehem terhadap Naomi menunjukkan kedudukan Naomi sebagai penduduk asli yang tidak dapat ditolak kedatangannya. Sebagai penduduk asli, ia memiliki hak yang sama dengan orang Israel lainnya di Betlehem-Yehuda; hak untuk tinggal, menjalin relasi sosial dengan keluarga, memiliki keluarga, mendapat pelayanan dan perlindungan hukum yang layak sebagaimana aturan adat Israel yang berlaku. ${ }^{31}$ Hak politisnya terjamin ketika ia ketika

${ }^{28}$ W. Bruegemann, "The Land : Place as Gift,: Promise and Chalenge in Biblical Faith", (London: SPCK, 2002), 3

${ }^{29}$ Jhon Inge," A Christian Theology of Place", (England: Ashgate,2003), 36

30 Nizzim Amzallag, "Furnace Remelting as the Expressi on of YHWH's Holiness: Evidence from the Meaning of qannā(קנא) in the Divine Context", Journal of Biblical Literature.Vol. 134 No. 2 (2015): 233.

31 Terry Giles \& William J Doan, “The Story Of Naomi -The Book of Ruth: From Gender to Politics",(Oregon: Cascade Books, 2016), 40 
ia hendak menjual tanah warisan leluhurnya dimana tanah leluhurya tersebut menjadi topik pembicaraan para tua-tua yang berakhirnya penebusan tanah milik leluhurnya oleh Boas salah seorang sanak keluarga Elimelek selaku penebus yang sah.

\section{Rekomendasi Untuk Penelitian Lanjutan}

Kajian dalam tulisan dan implikasinya secara langsung dalam dengan kehidupan masyarakat kusususnya Nusa Tenggara Timur tentunya masih meninggalkan Tanya yang belum dibahas dalam kajian ini, tentunya yang berkaitan dengan konteks NTT. Oleh sebab itu, penulis merekomendasikan kepada peneliti berikut yang tertarik membahas thema tentang konteks migrasi di NTT untuk mengkajinya dengan pendekatan kuantitatif untuk mengetahui sejauh mana dampak migrasi itu bagi keberlangsungan hidup masyarakat.

\section{Kesimpulan}

Pilihan Naomi kembali ke Betlehem tanah leluhurnya pasca tragedy di Moab tersirat persepsi Naomi tentang makna ekonomis, budaya, politis dan religious dari tanah leluhurnya. Berdasarkan Rut 1:6-19-22, Naomi menegaskan kembali mengakui tanah leluhur nya sebaga "ibu" yang telah melahirkannya, bahkan selalu setia menyambut kepulangannya, mengobati semua kepedihan hidupnya selama di Moab. Tanah leluhurnya menjadi harapan satu-satunya yang menjamin kesejahtraan hidupnya di masa tuanya. Sekaligus tempat paling menjamin hak-hak hidup dan relasi sosial-nya sebagai seorang janda. Khususnya tempat yang aman untuk beribadah dengan setia kepada Allah sang pemberi dan pemilik tanah leluhurnya. Kesadaran Naomi menjadi kesadaran orang Israel dalam zaman Hakim-Hakim untuk tetap bertahan hidup di atas tanah milik mereka tanah leluhur mereka dan tetap mengupayakan kesejahtraan tanahnya dengan rasa hormat kepada Allah sang pemilik.

\section{Rujukan}

Amzallag, Nizzim, "Furnace Remelting as the Expressi on of YHWH's Holiness: Evidence from the Meaning of qannā(קנא) in the Divine Context", Journal of Biblical Literature. Vol. 134 No. 2 (2015).

Atkinson, David, Seri Pemahaman dan Penerapan Amanat Alkitab Masa Kini Rut, (Jakarta: Yayasan Bina Kasih), 2005.

Benitez, Milton Acosta, "Commentary on Ruth", Journal of Latin American Theology: Christian Reflection from the Latino South, Volume 11 No 11, 17, diakses 26 Mei 2019. https://books.google.co.id/books?id=Of1JDAAAQBAJ\&pg=PA27\&dq=naomi+on+I ournal\&hl=id\&sa=X\&ved=0ahUKEwicn72qrrjiAhXJPI8KHRftAi4Q6AEIMTAB\#v=on epage\&q=naomi \%20on \%20Journal\& $\mathrm{f}=$ false.

Brick, Van den B, Tafsiran Rut dan Ester, Jakarta: BPK Gunung Mulia, 1970

Bruegemann, W, The Land : Place as Gift,: Promise and Chalenge in Biblical Faith, London: SPCK, 2002.

Cleland, James T, The Intepreters Bible Vol. 2, Nashville, Abingdon Press, 1953.

Dillistone, F.W, The Power of Symbol: Daya Kekuatan Symbol, Yogyakarta: Kanisius, 2002.

Douglas, J.D, Ensiklopedi Masa Kini Jilid 1: A-L, Jakarta: YKBK/OMF, 2007.

Dubin, Lois C, Fullness and Emptiness: Meditation on Naomi's Tale in the Book of Ruth, dalam Judith A. Kates \& Gail T Reimer, Reading Ruth : Contemporary Women Reclaim a Sacred Story, Amerika: Ramdom House, 1994.

Giles, Terry \& Doan, William J, The Story Of Naomi -The Book of Ruth: From Gender to Politics, Oregon: Cascade Books, 2016. 
Gottwald, Norman K, A Hebrew Bible: A Socio Literary Introduction, London: Oxford University Press, 1962.

Hamlin, E. Jhon, Surely Is The Future: A Commentary On The Book of Ruth, Amerika: Eerdmans Company, 1996.

Hubbard, Robert L, The Book of Ruth, America: Erdmass Publishing, 1943.

Inge, Jhon. A Christian Theology of Place, (England: Ashgate, 2003.

Karman, Yongki, Bunga Rampai Teologi Perjanjian Lama, Jakarta:BPK GM, 2004. Tafsiran Kitab Rut, Jakarat: BPK Gunung Mulia, 2009.

Kennedy, J. Hardee, Ruth dalam The Broadman Bible Commentary Volume 2: Leviticus - Ruth, Broadman Press, 1970

Kolimon, Merry, Teologi Ramah Tanah di Timor Barat, dalam Zakaria Ngelow \& Lady (ed), Teologi Tanah: Perspektif Kristen terhadap ketidakadilan Sosio-ekologis di Indonesia, Makassar: Oase Intim, 2015.

Maiaweng, Peniel C. D. \& Ukung, Christina, “Apakah Rut, Perempuan Moab Adalah Penyembah TUHAN?" Jurnal JAFFRAY, Vol. 16, No. 2, diakses 26 Mei 2019 https://media.neliti.com/media/publications/264784-apakah-rut-perempuanmoab-adalah-penyemb-5f93f726.

May, Herbert G, The Books of Ruth, dalam: Interpreter's Concise Commentary Vol. II: Old Testament History, USA: The Parthenon Press, 1984.

Pekerti, Anugrah, Globalisasi, Pembelajaran dan Kemanusiaan: Tantangan untuk cendekiwan Kristen, dalam seri membangun Bangsa: Pembelajaran memasuki Era Kesejagatan, Jakarta: PT Sinar Agape Press, 1998.

Reed, W, A Recent Analisys of Grain from Ancient Dibon in Moab, dalam Robert L. Hubbard, The Book of Ruth, Amerika: Grand Rapid, 1943.

Sakenfeld, K. D., The Story of Ruth: Economic Survival In Reality Day: Essays in Archaelogical and Biblical Intrepretation, Atlanta: Scholars, 1999.

Naomi's Cry: Reflection on Ruth 1: 20-22, dalam Brent A. Strawn dan Nancy R. Bowen Miller, A God So Near: Essyas on Old Testament Theology in Honor of Patrick D, Winona Lake: Eisenbrauss, 2003.

Siquans, Agnethe, "Foreignness and Poverty in the Book of Ruth: A Legal Way for a Poor Foreign Woman to Be Integrated into Israel", Journal of Biblical Literature Vol. 128, No. 3 (Fall, 2) (2009).

Sitompul \& Beyer, Ulrich, Metode Penafsiran Alkitab, Jakarta: BPK Gunung Mulia, 2006.

Timo, Eben Nuban, Pewarta Firman Pecinta Budaya: Mendengar dan Melihat Allah dalam Tradisi, Jakarta: BPK Gunung Mulia, 2005. 